\title{
PENGEMBANGAN PERANGKAT PEMBELAJARAN PADA POKOK BAHASAN LARUTAN PENYANGGA DENGAN POLA DEDUKTIF
}

Putu Candra Yuni Artini, Ida Bagus Nyoman Sudria, Ngadiran Kartowasono

Universitas Pendidikan Ganesha

Singaraja, Indonesia

\section{A R T I C L E I N F O}

Article history:

Received 25 September 2019

Received in revised form

1 October 2019

Accepted 4 October 2019

Available online 12 October 2019

\section{Kata Kunci:}

perangkat pembelajaran, pendekatan saintifik, pola deduktif, larutan penyangga

\begin{abstract}
Abstrak
Penelitian dan pengembangan pendidikan (R\&D) ini bertujuan (1) mengembangkan dan mendeskripsikan karakteristik perangkat pembelajaran pola deduktif pada pokok bahasan larutan penyangga, (2) mendeskripsikan validitas perangkat pembelajaran yang dikembangkan dari hasil penilaian dan masukan ahli dan praktisi. R\&D mengikuti prosedur Borg dan Gall yang dibatasi sampai tahap validasi produk dan uji keterbacaan. Data hasil penelitian ini meliputi hasil analisis kebutuhan, rancangan prototipe perangkat pembelajaran, pembuatan perangkat pembelajaran, validasi produk, dan deskripsi karakteristik perangkat pembelajaran larutan penyangga dengan pola deduktif. Hasil-hasil penelitian dianalisis secara kualitatif. Hasil analisis kebutuhan menunjukkan diperlukannya perangkat pembelajaran dengan pendekatan saintifik pola deduktif. Produk yang dihasilkan berupa prototipe perangkat pembelajaran larutan penyangga dengan pola deduktif meliputi RPP, LKS, teks materi pelajaran, dan instrumen penilaian. Karakteristik RPP, LKS, dan teks
\end{abstract} materi pelajaran yang dikembangkan adalah menyajikan isi dengan urutan konsep dan tahapan penalaran yang sama (deduktif). Hasil validasi menunjukkan sebagian besar aspek perangkat pembelajaran mendapat rata-rata penilaian dengan kategori baik dari validator. Hasil uji keterbacaan pada siswa SMA juga menunjukkan tingkat keterbacaan LKS, teks materi, dan tes hasil belajar dalam kategori baik. Dengan demikian, perangkat pembelajaran larutan penyangga dengan pola deduktif yang telah dikembangkan memiliki validitas memadai (baik).

\begin{abstract}
This education research and development (R\&D) was aimed to (1) develop and describe the characteristic of deductive learning tools on the topic of buffer solution, (2) describe the validity of developed learning tools from validators' assessment results. R\&D follow procedures by Borg and Gall that is limited until product validation and readabilty test. Results of the research were need assessment, planning of learning tools prototype, making of learning tools, validation data, and characteristic description of deductive learning tools. The research results were analyzed qualitatively. The need assessment result show that scientific deductive learning tools were needed. The products produced were scientific deductive learning tools which included lesson plan, worksheet, reading text, and assessment instrument. The characteristic of lesson plan, worksheet, and reading text are presenting content with same concept arrangement and reasoning step (deductive). Validation result show that most aspects of developed learning tools got good category judgement from validators. The readability test result also showed that level of students understanding on developed learning tools was in good category. Therefore, deductive learning tools on the topic of buffer solution that had been developed have good validity.
\end{abstract}




\section{PENDAHULUAN}

Carin dan Sund (1975) mendefinisikan sains sebagai pengetahuan yang sistematis dan tersusun secara teratur, berlaku umum (universal), dan berupa kumpulan data hasil observasi dan eksperimen. Pada hakikatnya, sains memiliki dua dimensi, yaitu sains sebagai produk dan sains sebagai proses (inkuiri). Oleh karena keterampilan proses sains (inkuiri) sebagai hasil belajar sains sekaligus sebagai cara belajar sains yang efektif, maka pembelajaran sains sebagai proses (inkuiri) sangat ditekankan dalam belajar sains secara efektif. Inkuiri melibatkan proses berpikir yang menghendaki pola berpikir yang konsisten, contohnya pola berpikir deduktif yang menggunakan paradigma positivistik. Pola berpikir yang tidak konsisten seperti menggabung pola induktif dan deduktif secara sembarangan cenderung menimbulkan kebiasaan belajar secara menghafal (Sudria, et al., 2013).

PISA (Programme for International Student Assessment) merupakan sebuah studi berskala internasional terhadap kemampuan matematika, sains dan membaca siswa berusia 15 tahun yang diadakan setiap 3 tahun sekali, terhitung sejak tahun 2000. Berdasarkan hasil PISA pada tahun 2000 sampai 2012, Indonesia konsisten menempati peringkat sepuluh terbawah dalam literasi sains dibandingkan negara lain peserta PISA (OECD, 2002; OECD 2005; OECD 2009; OECD 2010; dan OECD 2014). Fakta tersebut menunjukkan bahwa kualitas pendidikan sains di Indonesia untuk tingkat sekolah menengah masih rendah dan tertinggal dibandingkan negara lain peserta PISA.

Rendahnya kualitas pendidikan sains di Indonesia disebabkan oleh kebiasaan belajar siswa dengan menghafal (Sudria, et al., 2013). Kebiasaan belajar dengan cara menghafal salah satunya disebabkan karena guru kurang konsisten dalam menerapkan kaidah-kaidah belajar secara deduktif maupun belajar secara induktif untuk mengoptimalkan pengembangan keterampilan proses sains. Di samping itu, Sudria, et al. (2013) belum menemukan RPP, LKS, buku pelajaran siswa, dan media pembelajaran untuk suatu unit pembelajaran Kimia SMA sebagai suatu perangkat pembelajaran yang secara konsisten mengikuti pola penalaran induktif/deduktif digunakan di provinsi Bali, dan banyak organisasi konsep belum optimal mengikuti hierarki belajar konsep kimia sesuai pola penalaran yang digunakan.

Pembelajaran sains menekankan pada pemberian pengalaman langsung untuk mengembangkan kompetensi siswa agar mampu menjelajahi dan memahami alam sekitar melalui metode ilmiah yang ditekankan dalam bentuk 5M (mengamati, menanya, mengumpulkan informasi, mengasosiasikan dan mengomunikasikan) dalam Kurikulum 2013 (Kemendikbud, 2014). Metode ilmiah tersebut berpengaruh terhadap pembelajaran sains yang tidak hanya dapat dilakukan melalui pendekatan induktif, tetapi juga dapat dilakukan melalui pendekatan deduktif yang taat asas. Belajar secara deduktif merupakan pengembangan penalaran mulai dari generalisasi (konsep, hukum, dan teori umum) kemudian mengurai menjadi particulars (contoh-contoh dan penerapan) yang mengarah pada penemuan turunan (derivative) dari konsep yang lebih umum. Pola berpikir deduktif yang mengikuti metode ilmiah secara berurutan dimulai dari pengakuan kebutuhan untuk membuktikan kebenaran/kejituan suatu teori (rumusan masalah pembuktian teori), merumuskan hipotesis derivatif sesuai dengan dasar teori awal/umum tersebut, merencanakan dan melaksanakan eksperimen pembuktian hipotesis, membuat simpulan berupa temuan-temuan ilmiah sebagai pembuktian kebenaran dasar teori umum tersebut, dan mengkomunikasikan hasil pembuktian (Thomond, 2004). Perbaikan kualitas pembelajaran sains dapat dilakukan melalui perbaikan pembelajaran sains yang menekankan pada pembinaan keterampilan berpikir penemuan secara deduktif yang taat asas dalam membangun pengetahuan secara pemahaman dan bermakna.

Sebagai salah satu cabang dari sains, kimia dapat dipandang sebagai produk, yang meliputi fakta-fakta, konsep-konsep dan hukum-hukum dasar kimia. Kimia juga dapat dipandang sebagai proses berpikir maupun proses konkret seperti keterampilan praktikum. Pemahaman konsep kimia yang bermakna dapat dicapai melalui penekanan pembelajaran mengikuti pola deduktif. Pembelajaran aspek kimia yang melibatkan keterkaitan tiga aspek yakni aspek makroskopis/sifat teramati, mikroskopis/partikel materi sebagai latar fenomena, dan simbolik seperti lambang kimia sebagai simplifikasi aspek mikroskopik dan fenomena makroskopik merupakan konteks yang efektif dalam pengembangan keterampilan berpikir deduktif sebagai dasar berpikir kritis dan kreatif (Sudria, et al., 2013).

Topik-topik dalam ilmu kimia dapat dipelajari dan diajarkan dengan mengikuti pola deduktif. Pembelajaran dengan pola deduktif sangat baik diterapkan pada pokok bahasan yang memfasilitasi pembuktian penemuan konsep melalui eksperimen. Salah satu topik yang memfasilitasi penemuan konsep melalui eksperimen adalah topik larutan penyangga (buffer). Larutan penyangga adalah salah satu topik kimia yang sangat dekat dengan kehidupan sehari-hari. Sistem larutan penyangga dalam obat tetes mata dan sistem larutan penyangga dalam makhluk hidup adalah contoh- 
contoh dari penerapan konsep larutan penyangga dalam kehidupan sehari-hari. Pembelajaran larutan penyangga dengan pola deduktif dapat dilakukan melalui penurunan konsepsi konsep-konsep larutan penyangga dari konsep-konsep umum tentang asam-basa, teori asam-basa Bronsted-Lowry, dan kesetimbangan kimia yang telah dimiliki/dipelajari siswa. Pembuktian penurunan konsep-konsep tersebut bisa dibuktikan melalui eksperimen. Dengan demikian, pokok bahasan larutan penyangga dapat di belajarkan dengan menggunakan pendekatan deduktif.

Dengan melakukan eksperimen, siswa mendapatkan pengalaman belajar mulai dari mencari pengetahuan yang relevan (telaah awal teks belajar, dan/atau lingkungan sekitar), merumuskan masalah, menyusun hipotesis, merancang penyelidikan atau percobaan, mengamati, mengumpulkan dan menganalisis data hasil penelitian, mengkomunikasikan pengetahuan yang diperoleh, dan memecahkan masalah yang ditemukan dalam kehidupan sehari-hari yang digunakan untuk menerapkan/ mengaplikasikan komponen-komponen keterampilan proses sains.

Studi lapangan berupa analisis dokumen yang dilakukan pada tahun 2013 oleh Sudria, et al. sebagai payung dari penelitian ini, menghasilkan bahwa LKS dan teks materi pelajaran dalam buku pelajaran merupakan perangkat pembelajaran yang paling mendekati representasi urutan langkahlangkah kegiatan belajar dan suasana pola berpikir di lapangan, namun LKS dan teks materi pelajaran yang digunakan dalam pembelajaran tidak melibatkan siswa dalam merumuskan masalah, hipotesis, dan membuat rancangan eksperimen. Peran keterampilan berpikir deduktif sebagai dasar keterampilan proses sains kurang diberdayakan secara optimal dalam pembelajaran oleh guru. Selain itu, hasil penyebaran angket yang telah dilakukan Sudria, et.al. (2013) sebagai payung dari penelitian ini mendapatkan pengakuan tentang pentingnya konsistensi guru dalam pengimplementasian pendekatan deduktif melalui angket cukup tinggi (sekitar 55\%). Data pengakuan melalui angket pilihan, juga didukung oleh pernyataan tambahan guru melalui butir pernyataan terbuka. Sebesar $50 \%$ guru secara eksplisit menyatakan perlunya pengembangan perangkat pembelajaran dengan pendekatan deduktif secara konsisten untuk melatih berpikir deduktif. Ini menunjukkan bahwa guru sesungguhnya mengakui pentingnya pendekatan deduktif dalam pembelajaran sains, tetapi penerapannya dalam perangkat pembelajaran untuk mengoptimalkan pembinaan keterampilan proses sains masih belum memadai.

Untuk dapat menyelenggarakan pembelajaran kimia pada topik larutan penyangga dengan pola deduktif, dibutuhkanlah perangkat pembelajaran yang juga konsisten mengikuti pola deduktif. Penyusunan perangkat pembelajaran (isi dan organisasi RPP, LKS, dan teks materi pelajaran (terkait) untuk suatu unit pembelajaran) yang sama dan selaras dengan pola deduktif akan menjamin konstruksi konsepsi melalui kegiatan-kegiatan belajar yang mengikuti pola berpikir deduktif. Perangkat pembelajaran larutan penyangga dengan pola deduktif ini, semestinya dikembangkan melalui penelitian dan pengembangan (R\&D) untuk mendapatkan perangkat pembelajaran larutan penyangga dengan pola deduktif yang bersifat valid dan reliabel.

\section{METODE}

Penelitian ini termasuk ke dalam jenis penelitian dan pengembangan (R\&D) pendidikan mengikuti Borg dan Gall (1989) yang terbatas pada tahap penelitian dan pengumpulan data (analisis kebutuhan), perencanaan, pengembangan produk, dan validasi produk Produk yang dihasilkan berupa perangkat pembelajaran pada topik larutan penyangga dengan pola deduktif meliputi RPP, LKS, teks materi pelajaran, dan instrumen penilaian.

Subyek dan obyek penelitian ini sesuai dengan tahapan R\&D. Subyek untuk studi literatur adalah Permendikbud Nomor 103 tahun 2014, buku-buku kimia SMA kelas XI (Kurikulum 2013), dan artikel-artikel terkait pola deduktif. Obyek untuk studi literatur berupa kompetensi bahan kajian kimia yang meliputi konsep-konsep terkait topik larutan penyangga. Subyek pada tahap perencanaan adalah prosedur dan rancangan RPP, LKS, teks materi pelajaran, dan instrumen penilaian. Obyeknya adalah kesesuaian prosedur dan rancangan RPP, LKS, teks materi pelajaran dan instrumen penilaian dengan kriteria pendekatan saintifik pola deduktif. Subyek pada tahap pengembangan produk adalah draf RPP, LKS, teks materi pelajaran dan instrumen penilaian. Obyeknya adalah kesesuaian isi dan organisasi RPP, LKS, teks materi pelajaran dan instrumen penilaian dengan draf perangkat pembelajaran. Subyek pada tahap uji validitas adalah dua orang dosen jurusan Pendidikan Kimia Undiksha sebagai ahli isi dan ahli pedagogi, tiga orang guru kimia SMA, dan 12 orang siswa SMA untuk uji keterbacaan siswa. Obyek pada tahap ini adalah hasil penilaian dari ahli (isi dan pedagogi) dan guru, serta hasil uji keterbacaan perangkat pembelajaran larutan penyangga dengan pola deduktif.

Penelitian ini dimulai dengan analisis kebutuhan. Analisis kebutuhan secara umum sudah dilakukan oleh Sudria, et al. (2013) yang menjadi payung penelitian ini. Analisis kebutuhan tambahan terbatas pada studi literatur untuk menyesuaikan produk pada Kurikulum 2013. Tahapan kedua 
adalah tahap perencanaan berupa pembuatan analisis konsep topik larutan penyangga, perencanaan sinergisitas perangkat pembelajaran larutan penyangga dengan pola deduktif dan perancangan asesmen. Pembuatan analisis konsep pada topik larutan penyangga didasarkan pada analisis konsep menurut Herron, et al. (1977). Pada tahap ini juga dilakukan clustering (pembagian unit kegiatan pembelajaran) berdasarkan Dick dan Carey (1985). Sinergisitas perangkat pembelajaran pada pokok bahasan larutan penyangga dengan pola deduktif direncanakan dengan tujuan untuk memastikan perangkat pembelajaran tetap selaras, yakni isi dan urutan konsep dalam masing-masing perangkat pembelajaran adalah sama. Perancangan asesmen dilakukan dalam bentuk pembuatan tabel rancangan asesmen agar mampu mengukur ketercapaian setiap indikator pencapaian kompetensi yang diprogramkan.

Pada tahap pengembangan produk, dilakukan pembuatan prototipe perangkat pembelajaran itu sendiri. Pengembangan perangkat pembelajaran dimulai dengan memperhatikan KI dan KD sebagai mandat kurikulum, materi, dan pendekatan saintifik sebagai optimalisasi keterampilan proses sains. Perangkat pembelajaran inti meliputi RPP, instrumen penilaian, LKS, dan teks materi pelajaran yang mengikuti pendekatan saintifik sesuai dengan pedoman implementasi Kurikulum 2013 dengan pola berpikir deduktif secara konsisten.

Validasi produk melibatkan dua orang dosen jurusan Pendidikan Kimia sebagai ahli isi dan ahli pedagogi, dan tiga orang guru kimia SMA. Uji keterbacaan melibatkan 12 orang siswa SMA. Kategori penilaian validator untuk setiap aspek perangkat yang dikembangkan digolongkan menjadi empat, yakni sangat baik (SB), baik (B), kurang (K) dan sangat kurang (SK). Setelah proses-proses tersebut, selanjutnya dilakukan revisi.

Semua data hasil penelitian dianalisis secara kualitatif. Data analisis kebutuhan, perencanaan produk, dan pembuatan produk dianalisis secara umum dan disajikan secara deskriptif. Data hasil validasi dianalisis per aspek penting dalam perangkat pembelajaran melalui (a) modus penilaian dari kelima validator, dan (b) analisis logis terhadap butir-butir yang belum mendapat penilaian baik. Produk perangkat pembelajaran dikatakan memiliki validitas memadai apabila mayoritas aspek perangkat pembelajaran minimal memenuhi kategori baik.

\section{HASIL DAN PEMBAHASAN}

Hasil

Hasil studi literatur terhadap Permendikbud No. 103 tahun 2014 menyatakan bahwa pembelajaran pada Kurikulum 2013 menggunakan pendekatan saintifik atau pendekatan berbasis proses keilmuan (Kemendikbud, 2014). Pendekatan saintifik dapat dipandang melalui dua perspektif, yakni perspektif fenomenologis (induktif) dan perspektif positivistik (deduktif). Belajar sains yang efektif melibatkan kebiasaan mental (habits of mind) yang tidak dapat lepas dari berpikir. Salah satu dari dua pola berpikir dasar adalah pola deduktif. Belajar sains secara bermakna seperti alur peta konsep umumnya keterampilan berpikir deduktif. Keterampilan berpikir deduktif adalah membuktikan kebenaran suatu hipotesis teoritik. Felder dan Silverman (1988) menyatakan bahwa tipe belajar deduktif merupakan salah satu jenis aktivitas utama untuk mengakses pendekatan umum belajar dalam dimensi organisasi belajar atau mengajar. Sudria, et.al. (2013) menyatakan bahwa pembelajaran sains menekankan sains sebagai proses inkuiri. Inkuiri melibatkan proses berpikir yang menghendaki pola berpikir yang konsisten seperti pola berpikir deduktif yang menggunakan paradigma positivistik. Benchmark for Science Literacy yang dirumuskan oleh American Association for Advancement of Science atau AAAS (1993) juga menekankan belajar sains sebagai proses inkuiri pada kelas XII ke bawah.

Dengan demikian, pembelajaran larutan penyangga di kelas XI dapat dipelajari oleh siswa SMA dengan pola deduktif secara konsisten. Pola berpikir yang tidak konsisten seperti menggabung pola induktif dan deduktif secara sembarangan cenderung menggagalkan terjadinya alur berpikir itu dan menimbulkan kebiasaan belajar secara menghafal. Pelaksanaan pendekatan saintifik, dalam hal ini dengan pola deduktif yang konsisten dan taat asas sangatlah diperlukan.

Perangkat pembelajaran dengan pola deduktif dapat dikembangkan pada pokok bahasan larutan penyangga yang sangat kaya dengan keterpaduan kajian aspek makroskopik, mikroskopik, dan simbolik, serta kaya dengan konteks fenomena di tubuh makhluk hidup dan industri. Kompetensi dasar (KD) dari masing-masing kompetensi inti (KI) dalam Kurikulum 2013 untuk SMA/MA sesuai Permendikbud nomor 59 tahun 2014 (Kemendikbud, 2014). Analisis konsep menurut Herron et.al. (1977) pada topik larutan penyangga ini dilakukan untuk kemudian dijadikan dasar dalam pengelompokan (cluster) konsep-konsep ke dalam unit-unit pembelajaran berdasarkan Tabel 01. Ada tujuh jenis konsep yang mungkin teridentifikasi yakni 1) konsep konkret (K), (2) konsep tanpa contoh yang diamati (Ab), (3) konsep abstrak dengan contoh konkret (CaCk), (4) konsep berdasarkan prinsip 
(BP), (5) konsep yang melibatkan simbol (S), (6) konsep yang menyatakan proses (MP), dan (7) konsep yang menyatakan sifat (MS). Sesuai dengan pengelompokan jenis konsep yang terdapat pada Tabel 01 dengan mempertimbangkan keutuhan aspek belajar dalam suatu unit pembelajaran, alokasi waktu, dan kepraktisan pembelajaran dengan pola deduktif, maka unit-unit kegiatan pembelajaran pokok bahasan larutan penyangga juga dikelompokkan menjadi tiga unit, yakni unit pembelajaran I mencakup definisi, komponen, dan pH larutan penyangga; unit pembelajaran II mencakup cara kerja dan sifat larutan penyangga; dan unit pembelajaran III mencakup manfaat larutan penyangga. Perangkat pembelajaran untuk setiap unit kegiatan pembelajaran meliputi RPP, LKS (termasuk media), teks materi pelajaran, dan instrumen penilaian. Struktur perangkat pembelajaran dengan pola deduktif untuk setiap unit pembelajaran sama, yakni mengikuti tahapan kegiatan 5 M (mengamati, menanya, mengumpulkan data, mengasosiasi, dan mengkomunikasikan) yang diamanatkan oleh Kurikulum 2013. Alokasi waktu setiap unit pembelajaran yakni unit pembelajaran I dengan alokasi waktu 3 jam pelajaran, unit pembelajaran II alokasi waktu 3 jam pelajaran, unit pembelajaran III alokasi waktu 2 jam pelajaran, dan post tes dengan alokasi waktu 2 jam pelajaran. Perbedaan setiap jenis/komponen perangkat pembelajaran untuk setiap unit pembelajaran dalam setiap tahapan, yakni RPP memuat rencana pelaksanaan pembelajaran, LKS berisikan tagihan kegiatan terhadap siswa, teks materi pelajaran menyajikan deskripsi materi pelajaran, dan instrumen penilaian sebagai alat penilaian yang mengukur indikator pencapaian kompetensi.

Sistematika setiap perangkat pembelajaran yang dikembangkan mengikuti tahapan pendekatan saintifik pola deduktif. Sistematika RPP secara umum mencakup identitas, penjabaran KD menjadi indikator pencapaian kompetensi, tujuan pembelajaran, uraian materi (konsep-konsep prasyarat dan konsepsinya, konsep yang akan dikaji dan dan konsepsinya, dan uraian materi secara ringkas), strategi pembelajaran (model, pendekatan, metode, dan teknik pembelajaran yang dinyatakan secara eksplisit), tabel rancangan strategi pembelajaran yang menunjukkan hubungan satu atau beberapa indikator terkait dengan strategi pembelajaran (metode dan teknik pembelajaran), penilaian (target, bentuk, instrumen, dan prosedur pelaksanaan asesmen), serta alat dan sumber belajar.

Tabel 01. Kelompok konsep yang dibangun dan konsep prasyaratnya

\begin{tabular}{|c|c|c|c|c|}
\hline No & Konsep yang dibangun & $\begin{array}{l}\text { Jenis } \\
\text { Konsep }\end{array}$ & $\begin{array}{l}\text { Konsep prasyarat dan jenis } \\
\text { konsep }\end{array}$ & $\begin{array}{c}\text { Alokas } \\
\text { waktu }\end{array}$ \\
\hline \multicolumn{5}{|c|}{ Kelompok konsep unit 1} \\
\hline 1 & Efek ion senama & $\mathrm{CaCk}$ & Larutan (CaCk), asam lemah (Ab), & $3 \mathrm{JP}$ \\
\hline 2 & Larutan penyangga & $\mathrm{K}$ & basa lemah $(\mathrm{Ab})$, kesetimbangan & \\
\hline 3 & Larutan penyangga asam & $\mathrm{K}$ & ionisasi asam lemah $(\mathrm{Ab})$ & \\
\hline 4 & Larutan penyangga basa & $\mathrm{K}$ & kesetimbangan ionisasi basa lemah & \\
\hline 5 & pH larutan penyangga asam & $\mathrm{BP}$ & (Ab), asas Le Chatelier (BP), asam & \\
\hline 6 & pH larutan penyangga basa & $\mathrm{BP}$ & $\begin{array}{l}\text { konjugasi }(\mathrm{Ab}) \text {, basa konjugasi } \\
(\mathrm{Ab}) \text {, garam }(\mathrm{K}), \mathrm{pH}(\mathrm{BP}) \text {, tetapan } \\
\text { ionisasi asam } \mathrm{Ka}(\mathrm{K}) \text {, tetapan } \\
\text { ionisasi basa } \mathrm{Kb}(\mathrm{K}) \text {, konsentrasi } \\
(\mathrm{K})\end{array}$ & \\
\hline \multicolumn{5}{|c|}{ Kelompok konsep unit 2} \\
\hline 6 & $\begin{array}{l}\text { Ketahanan larutan penyangga asam } \\
\text { terhadap penambahan asam }\end{array}$ & $\mathrm{K}$ & $\begin{array}{l}\text { Larutan penyangga asam }(\mathrm{K}) \text {, } \\
\text { larutan penyangga basa }(\mathrm{K}), \mathrm{pH}\end{array}$ & $3 \mathrm{JP}$ \\
\hline 7 & $\begin{array}{l}\text { Ketahanan larutan penyangga basa } \\
\text { terhadap penambahan asam }\end{array}$ & $\mathrm{K}$ & larutan penyangga (BP), & \\
\hline 8 & $\begin{array}{l}\text { Ketahanan larutan penyangga asam } \\
\text { terhadap penambahan basa }\end{array}$ & $\mathrm{K}$ & & \\
\hline 9 & $\begin{array}{l}\text { Ketahanan larutan penyangga basa } \\
\text { terhadap penambahan basa }\end{array}$ & $\mathrm{K}$ & & \\
\hline \multicolumn{5}{|c|}{ Kelompok konsep unit 3} \\
\hline 10 & Sistem penyangga karbonat & $\mathrm{K}$ & Larutan penyangga (K), pH larutan & $2 \mathrm{JP}$ \\
\hline 11 & Sistem penyangga fosfat & $\mathrm{K}$ & penyangga (BP), ketahanan larutan & \\
\hline 12 & Sistem penyangga asam amino & $\mathrm{K}$ & $\begin{array}{l}\text { penyangga terhadap penambahan } \\
\text { asam maupun basa }(\mathrm{K})\end{array}$ & \\
\hline
\end{tabular}


Setiap LKS terdiri atas beberapa rangkaian tagihan yang dirancang sesuai dengan tahapan pendekatan saintifik pola deduktif dan alokasi waktu per unit pembelajaran. Teks materi pelajaran topik larutan penyangga dikembangkan sebagai salah satu sumber informasi materi larutan penyangga yang konsisten menggunakan pendekatan saintifik dengan pola deduktif. Setiap tahapan pendekatan saintifik dalam teks materi tidak ditandai secara kaku (eksplisit) di dalam teks, tetapi disampaikan secara implisit. Teks materi pelajaran terdiri atas materi-materi yang mendukung pencapaian kompetensi inti, kompetensi dasar dan indikator pencapaian kompetensi yang meliputi (A) Materi pendahuluan tentang kesetimbangan ionisasi asam-basa; (B) Efek Ion Senama dan Larutan Penyangga; (C) pH Larutan Penyangga; (D) Cara Kerja dan Sifat Larutan Penyangga; (E) Ketahanan Larutan Penyangga terhadap Penambahan Asam atau Basa; (F) Manfaat Larutan Penyangga; dan Daftar Pustaka. Media pembelajaran sulit untuk disajikan sendiri, karena kebutuhannya tersebar terutama dalam LKS dan teks materi berupa kelengkapan perangkat praktikum dan format kerja dalam dalam LKS, media gambar (grafik perubahan $\mathrm{pH}$, partikel-partikel kesetimbangan larutan asam lemah/basa lemah, perubahan warna larutan penyangga dan bukan penyangga ketika penambahan asam atau basa) dalam LKS maupun teks materi pelajaran, dan fenomena manfaat larutan penyangga di dalam tubuh makhluk hidup.

Instrumen penelitian mencakup instrumen penilaian indikator kompetensi untuk KD dari KI1, KI-2, KI-3, dan KI-4. Rancangan asesmen digunakan sebagai kontrol dalam pembuatan instrumen penilaian (berupa tes hasil belajar (kognitif proses sains), rubrik penilaian sikap, dan rubrik penilaian keterampilan konkret) untuk memastikan terukurnya setiap indikator pencapaian. Bentuk penilaian meliputi pilihan ganda, uraian, dan performa/kinerja. Aspek pengetahuan diukur melalui tes pilihan ganda dan uraian. Jenjang kognitif soal-soal aspek pengetahuan disesuaikan dengan revisi taksonomi Bloom oleh Anderson, et al. (2001). Keterampilan abstrak diukur melalui kognitif keterampilan proses sains yang mengakomodasi aspek keterampilan proses sains.

Instrumen penilaian aspek pengetahuan terdiri atas 15 butir soal pilihan ganda, dan tiga butir soal uraian. Pembobotan skor dilakukan pada aspek pengetahuan untuk menyeimbangkan kontribusi tiap bagian soal pada skor akhir siswa. Keterampilan konkret diukur melalui penilaian unjuk kerja/ performa (dilengkapi dengan rubrik penilaian) yang terbatas pada performa kelompok untuk menilai kemampuan merancang, observasi, penggunaan alat dan bahan serta komunikasi hasil kegiatan dan rubrik penilaian laporan praktikum. Untuk sasaran afektif diukur melalui penilaian unjuk kerja/performa (dilengkapi dengan rubrik penilaian dan/atau melalui angket) berkaitan dengan KI-1 dan KI-2 sebanyak dua belas rubrik penilaian sikap.

Validasi produk dilakukan oleh ahli dan praktisi, sedangkan uji keterbacaan dilakukan pada siswa SMA. Validasi perangkat pembelajaran mencakup aspek-aspek umum perangkat pembelajaran, isi, dan organisasi. Hasil validasi nantinya akan menjadi indikator kualitas dan kelayakan perangkat pembelajaran pokok bahasan larutan penyangga yang telah dikembangkan. Secara umum, penilaian dari ahli isi, pedagogi, dan praktisi terhadap aspek umum, isi, dan organisasi perangkat pembelajaran pada pokok bahasan larutan penyangga dengan pola deduktif adalah baik (B) dan sangat baik (SB). Dua validator, yakni dosen selaku ahli pedagogi memberikan nilai kurang pada lima butir aspek dan praktisi ketiga memberikan nilai kurang pada tiga butir aspek dari 112 butir aspek penilaian perangkat pembelajaran. Selain memberikan penilaian dalam lembar validasi, validator juga memberikan masukan-masukan tambahan yang telah diakomodasi untuk direvisi oleh perangkat pembelajaran. Karakteristik dari perangkat pembelajaran pada pokok bahasan larutan penyangga yang telah dikembangkan adalah sinergis dan konsisten dalam menerapkan pendekatan saintifik pola deduktif.

Data hasil uji keterbacaan perangkat pembelajaran pokok bahasan larutan penyangga dengan pola deduktif pada 12 orang siswa menunjukkan bahwa keterbacaan LKS, teks materi pelajaran, dan tes hasil belajar berada di level baik dan sangat baik. Hal ini menunjukkan secara umum, LKS, teks materi pelajaran, dan tes hasil belajar yang nantinya akan secara langsung diberikan kepada siswa, dapat dipahami dengan baik.

\section{Pembahasan}

R\&D berhasil menghantarkan semua perangkat pembelajaran yang dikembangkan secara konsisten mengikuti pendekatan saintifik pola deduktif. Konsistensi masing-masing perangkat pembelajaran dalam menerapkan pendekatan saintifik pola deduktif disesuaikan dengan tabel konsistensi dan sinergi perangkat pembelajaran pola deduktif.

Organisasi penyajian perangkat pembelajaran untuk ketiga unit pembelajaran adalah sama, yakni mengikuti pendekatan saintifik pola deduktif, tetapi materi atau konsep yang dikaji berbeda. 
Instrumen penilaian (asesmen) menerapkan multi bentuk asesmen yang mencakup tiga aspek, yakni aspek pengetahuan, aspek keterampilan dan aspek sikap. Instrumen penilaian ini dibuat dan dipadu dalam rancangan asesmen.

Validasi perangkat pembelajaran pada pokok bahasan larutan penyangga dengan pola deduktif menunjukkan perangkat pembelajaran yang dikembangkan memiliki validitas memadai. Aspek-aspek perangkat pembelajaran mendapat nilai sangat baik (SB) diikuti mayoritas kedua dengan nilai baik (B). Hal yang sama juga terjadi pada uji keterbacaan. Namun, masih terdapat beberapa aspek yang mendapat nilai kurang sehingga perlu dipertimbangkan dan telah diakomodasi untuk revisi.

Penilaian dan masukan dari validator yang bersifat positif dan konstruktif menunjukkan perangkat pembelajaran pada pokok bahasan larutan penyangga dengan pola deduktif memiliki validitas yang memadai.

Karakteristik perangkat pembelajaran untuk masing-masing tahapan kegiatan 5M pola deduktif adalah sebagai berikut (1) Tahap mengamati: dalam RPP, guru menuntun siswa dalam melakukan kegiatan mengamati informasi awal; dalam LKS, terdapat tagihan untuk mencermati uraian materi/informasi awal yang terdapat pada teks pengantar; dalam teks materi pelajaran, disajikan uraian informasi materi sebagai pengantar terkait konsep yang dibelajarkan. (2) Tahap menanya: dalam RPP, guru menuntun siswa untuk membuat rumusan masalah investigatif terkait informasi awal; dalam LKS, terdapat tagihan untuk merumuskan masalah investigatif berdasarkan informasi awal; dalam teks materi pelajaran, disajikan secara implisit uraian pertanyaan investigatif terkait informasi/materi awal. (3) Tahap mengumpulkan informasi: dalam RPP, guru menuntun siswa dalam mengumpulkan informasi untuk menjawab rumusan masalah investigatif; dalam LKS, terdapat tagihan untuk mengumpulkan informasi dalam rangka menjawab rumusan masalah investigatif; dalam teks materi pelajaran, terdapat uraian kegiatan mengumpulkan informasi untuk menjawab rumusan masalah investigatif. (4) Tahap mengasosiasi: dalam RPP, guru menuntun siswa untuk melakukan analisis dan interpretasi data/informasi yang telah dikumpulkan untuk menjawab rumusan masalah investigatif; dalam LKS terdapat tagihan mengasosiasi dalam bentuk pertanyaan-pertanyaan yang mengarahkan siswa dalam menganalisis data; dalam teks materi pelajaran, terdapat uraian kegiatan mengasosias yang didapat melalui kegiatan sebelumnya. (5) Tahap mengkomunikasikan: dalam RPP, guru menuntun siswa untuk mengkomunikasikan simpulan (jawaban rumusan masalah investigatif); dalam LKS, terdapat tagihan simpulan dan mengkomunikasikan proses dan simpulan tersebut; dalam teks materi pelajaran, disajikan simpulan yang merupakan jawaban rumusan masalah investigatif.

Validitas perangkat pembelajaran pada pokok bahasan larutan penyangga dengan pola deduktif berdasarkan hasil validasi ahli dan praktisi adalah tergolong baik. Perangkat pembelajaran pada pokok bahasan larutan penyangga dengan pola deduktif yang dikembangkan memiliki keunggulan-keunggulan. Perangkat pembelajaran ini merupakan salah satu cara untuk menerapkan Kurikulum 2013 secara komprehensif. Kurikulum 2013 mengisyaratkan pembelajaran hendaknya dilaksanakan dengan pendekatan saintifik pola deduktif (Permendikbud Nomor 103 tahun 2014). Sajian aspek makroskopis, mikroskopis, dan simbolis serta manfaat larutan penyangga dalalm kehidupan juga mendukung pembelajaran kimia pada topik larutan penyangga dengan pendekatan saintifik. Hal serupa juga diungkapkan Subagia (2014), yang menyatakan mengaitkan pelajaran kimia dengan eksistensi kimia dalam kehidupan sehari-hari merupakan salah satu cara menuju paradigma baru pembelajaran kimia SMA untuk pengetahuan kimia yang baik dan benar. Konsistensi penerapan pendekatan deduktif dari perangkat pembelajaran yang dikembangkan dapat melatih keterampilan berpikir siswa. Dengan terbiasanya siswa berpikir deduktif maka siswa dapat menguasai salah satu keterampilan ilmiah. Penguasaan keterampilan berpikir dapat menghindarkan siswa dari belajar yang sifatnya menghafal (Sudria, et al., 2013).

\section{SIMPULAN DAN SARAN}

Perangkat pembelajaran pokok bahasan larutan penyangga dengan pola deduktif yang dihasilkan meliputi RPP, LKS, teks materi pelajaran, dan instrumen penilaian. Karakteristik perangkat pembelajaran pada pokok bahasan larutan penyangga dengan pola deduktif yakni sinergis dan konsisten mengikuti tahap-tahap pendekatan saintifik dengan pola deduktif. Validitas perangkat pembelajaran pada pokok bahasan larutan penyangga dengan pola deduktif berdasarkan hasil validasi ahli dan praktisi tergolong baik.

Bagi siswa, LKS dan teks materi pelajaran larutan penyangga berpola deduktif dari hasil penelitian ini dapat mendukung siswa belajar penemuan dengan pola deduktif. Bagi guru, perangkat pembelajaran pada pokok bahasan larutan penyangga dengan pola deduktif dari hasil penelitian ini dapat mendukung implementasi pendekatan saintifik Kurikulum 2013. Bagi peneliti, perlu adanya 
penelitian lebih lanjut untuk menentukan efektivitas pembelajaran dengan menggunakan pembelajaran pada pokok bahasan larutan penyangga dengan pola deduktif yang telah dikembangkan.

\section{DAFTAR RUJUKAN}

AAAS. (1993). Benchmarks for Science Literacy. New York: Oxford University Press.

Anderson, L. W., Krathwohl, D. R., Airasian, P. W., Cruikshank, K. A., Mayer, R. E., Pintrich, P. R., . . Wittrock, M. C. (Eds.). (2001). A Taxonomy for Learning, Teaching and Assesing. United States: Longman.

Borg, W. L., \& Gall, M. D. (1989). Educational Research: An Introduction. New York: Long Man.

Carin, A. A., \& Sund, R. (1975). Teaching Science Through Discovery. Ohio: Charles E. Meril Publisher.

Dick, W., \& Carey, L. (1985). The Systematic Design of Instruction. London: Scott, Foresman and Company.

Herron, \& et. al. (1977). Problems associated with concept analysis. Science Education. Vol 61. No. 2, 185-199.

Kemendikbud. (2014). Peraturan Menteri Pendidikan dan Kebudayaan Republik Indonesia No. 103 tahun 2014 tentang Pembelajaran pada Pendidikan Dasar dan Pendidikan Menengah. Jakarta: Menteri Pendidikan dan Kebudayaan Republik Indonesia.

OECD. (2002). PISA 2000 Technical Report. OECD, Paris. Diakses dari www.oecd.org/pisa

OECD. (2005). PISA 2003 Data Analysis Manual: SAS® Users, OECD, Paris. Diakses dari www.oecd.org/pisa

OECD. (2010). PISA 2009 Results: Executive Summary. OECD, Paris. Diakses dari www.oecd.org/pisa

OECD. (2014). PISA 2012 Results in Focus: What 15-year-olds know and what they can do with what they know.

Subagia, I. W. (2014). Paradigma Baru Pembelajaran Kimia SMA. Seminar Nasional FMIPA Undiksha (pp. 152-163). Singaraja: Universitas Pendidikan Ganesha.

Sudria, I. N., Kartowasono, N., Nurlita, F., \& Sya'ban, S. (2013). Pengembangan Perangkat Pembelajaran Kimia Dengan Pendekatan Berpikir Deduktif. Laporan Penelitian, Tidak dipublikasikan.

Thomond, P. N. (2004). Exploring and Describing Management Action for the Pursuit of Distruptive Innovation. Doctor Thesis. Cranfield University. Diakses 7 Desember 2014 dari dspace.lib.cranfield.ac.uk/.../P.\%20 Thomond\%20Thesis\%202004.pdf. 